\title{
Közösségi kapcsolatok a virtuális térben - a Facebook-használat statisztikai elemzése
}

\section{Bevezető}

Az internetes közösségek megjelenésével új korszak kezdődött a társadalmi kapcsolatok, a baráti közösségek kialakításában és az egymással történő kapcsolattartásban. A Facebook 2004-ben indult útjára, azóta emberek millióit tömöríti egy virtuális közösségbe. Társadalmi problémának vagy inkább egyre jelentősebb társadalmi jelenségnek nevezhető, hogy a fiatalok ebben a virtuális világban alakítják ki szoros emberi kapcsolataikat. Ennek a jelenségnek egyre több pozitív, illetve negatív következménye van az emberek életében. Egyrészt az ingyenes és gyors kapcsolattartás, az internet által biztosított személytelenség és távolság miatt könnyebb a kapcsolatok kialakítása, másrészt - éppen ezen okok miatt - az emberek egyre kiszolgáltatottabbak a virtuális térben. Napjainkra már számos kutatás készült, amely a Facebookkal vagy éppen a Facebook-függőséggel foglalkozik, hiszen fiataljaink - különös tekintettel a 14-23 éves korosztályra - a számítógép előtt ülve élik közösségi életük nagy részét; percről percre zenéket, fényképeket, hangulatokat, közelgő események programjait osztják meg egymással, de olyan is van, hogy házi feladattal kapcsolatos közérdekú információkat tesznek közzé egy-egy szúk csoport számára.

Az elmúlt években a Facebookot használók köre többszörösére bővült, így nem csoda, hogy világszerte (főleg az Amerikai Egyesült Államokban) és hazánkban is kutatásokat, kísérleteket végeztek a jelenséggel kapcsolatban. Ezen kutatások célja többnyire feltáró jellegú, de már évek óta megjelennek olyan elemzések is, amelyek meglepó jellemzőkre mutatnak rá. Ebben a munkában néhány ilyen jellegzetességet, érdekességet szeretnék bemutatni, majd két, egy nemzetközi és egy magyar, feltáró jellegú kutatás legfontosabb eredményeit ismertetem.

A fő célom pedig a PTE-BTK Szociológia Tanszékén a hallgatók segítségével lefolytatott online adatfelvétel közzététele és elemzése. A létrehozott adatbázis segítségével vizsgálom, hogy helyes volt-e a feltevés, miszerint a középiskolások és az egyetemisták máshogy, másra használják a Facebookot, mint egyetemista társaik. Kísérletet teszek arra, hogy a válaszadók egészét kisebb, a Facebook-használat szempontjából különféle jellegzetességgel rendelkező csoportokra bontsam. Az alkalmazott többváltozós elemzés során felhasználom a Facebook-használat jellegét implikáló legfontosabb vonásokat, valamint (az eredeti kutatás fő célját szem előtt tartva) egyik fontos komponensnek választottam az életkort és (korábbi kutatási eredményekből kiindulva) a nemet is. 


\section{Elméleti háttér}

A Facebookot Mark Zuckerberg fejlesztette ki a Harvardon három csoporttársával együtt. Egyetemi ,virtuális évkönyvnek” indult, majd - többféle megnevezés, illetve a szellemi tulajdonról szóló kisebb-nagyobb viták és perek után - mai formájában 2004. február 4-én kezdte meg múködését (Ballis é. n.).

A felhasználók száma Foster (2012) adatai alapján a kezdeti lassú gyarapodás után exponenciális ívú növekedésnek indult, 2008 augusztusára elérte a százmillió főt, az ezt követő röpke három év alatt (2011 szeptemberére) ez a szám megnyolcszorozódott, 2012 februárjára pedig világszerte összesen 845 millió felhasználóról beszélhetünk.

1. ábra: A Facebook felhasználóinak száma 2004-2011 (millió fö)

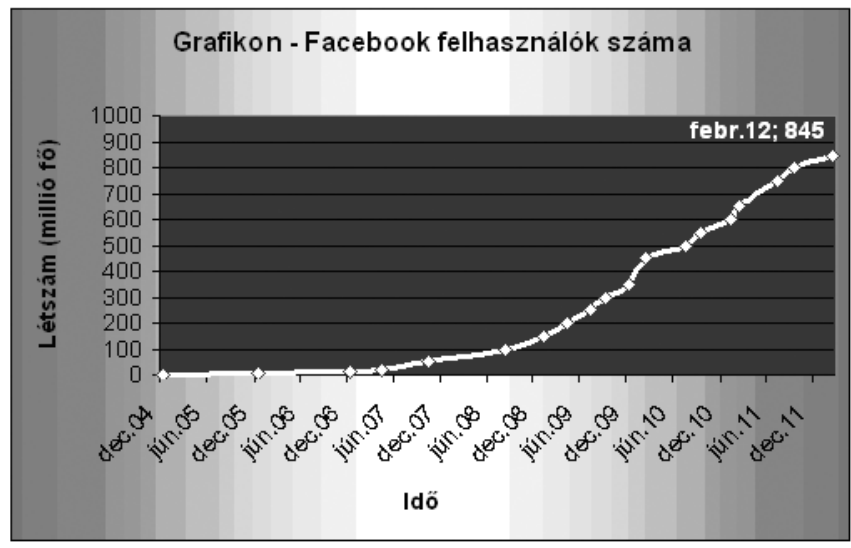

Forrás: Foster (2012) alapján saját szerkesztés

Éppen emiatt az extrém mértékú felhasználószám-bővülés miatt mondhatjuk, hogy a Facebook társadalmi jelenséggé vált. Ezt a feltevést alátámasztja az a tény, hogy a „Facebook regisztrált tagjainak száma az elmúlt egy évben közel megháromszorozódott, és mára megközelíti a 3 milliót" (Sütő 2011: 2.), valamint az, hogy mára már jelentős mennyiségú nemzetközi és magyar kutatás zajlott le, amely ezzel a témával foglalkozik. Sok szempontból közelítették már meg a Facebookot mint társadalmi jelenséget, mint szabadidő-eltöltési eszközt, mint bizonyos típusú emberek gyújtőhelyét, mint online hálózatot. Ezek közül néhányat érdekességként szeretnék ebben a munkában röviden felvillantani, majd két (egy nemzetközi és egy magyar), a Facebook-használókkal kapcsolatos feltáró munka eredményeit fogom bemutatni.

Van olyan elemzés, amely 63 profil alapján látja be - a tartalomelemzés módszerének segítségével -, hogy teljesen más jellegzetességei vannak a személyiségüket felvállaló Facebook-felhasználóknak, mint a korábbi, név nélküli, online közösségek tagjainak (Zhao és társai 2008). Joinson (2008) pedig két kutatást bonyolított le az Egyesült Királyságban, amelyek során szavakat, kifejezéseket gyűjtött összesen 378 
felhasználótól arra vonatkozóan, hogy hogyan használják a Facebookot, illetve mit élveznek benne. Mivel a Facebookot az egyik nagy online társadalmi hálózatnak is tekintjük, így matematikai modellekkel is megközelíthetô a múködése, lehet elemezni pl. a hálózati aktivitást, ahogy a Max Plank Intézet kutatóinak egy csoportja tette. Ők az interakciókat vizsgálták, valamint a hálózati szint jellegzetességeinek evolúcióját több mint 90.000 felhasználó 3,6 milliót meghaladó kapcsolatai alapján (Viswanath és társai 2009). Egy online felmérés 2603 hallgatójának válaszai alapján az Egyesült Államokban kimutatták, hogy a Facebook-használat intenzitása pozitívan hat az élettel való elégedettségre és a társadalommal kapcsolatos bizalomra (Valenzuela és társai 2009). 2011-ben a Cisco készített egy nemzetközi kutatást, ennek fókuszában nem a Facebook, hanem az internethasználat állt. 14 ország majdnem 1500 egyetemistájának vagy friss diplomásának adataiból kiindulva az derült ki, hogy 40\%-uk szerint az internet mára fontosabb, mint a randizás, és hogy az egyetemisták 27\%-a előrébb sorolja a Facebook-események követését mint akár a zenehallgatást vagy éppen a buliba járást (Cisco Connected World Technology Report 2011: 18.). Magyarországon egy speciális témának a kutatására fókuszált két PhD hallgató 2011 elején, ók azt vizsgálták, javíthatja-e a Facebook a tanár-diák kapcsolatot (Tóth-Mózer-Lévai 2011).

Részletesebben pedig egy 2010 novemberében lezajlott amerikai és egy 2011ben lekérdezett magyar kutatás eredményeit szeretném bemutatni. Az előbbiről, amely a Facebook-használattal kapcsolatos, Prievera (é. n.) írása számol be, a cél ezen kutatás esetén az egyetemisták és az egyetemet már elvégzett friss diplomások jellegzetes vonásainak összehasonlítása volt (a Cisco kutatásához hasonlóan). A kutatás egyik kiemelendô eredménye, hogy míg a válaszadó felhasználók 83\%-a közzéteszi családi állapotát, a politikai és vallási nézeteket inkább a férfiak hozzák nyilvánosságra, közülük is inkább az egyetemisták. A válaszadók majdnem $80 \%$-a naponta egyszer fellép a Facebookra, míg 49,2\%-uk naponta legalább háromszor teszi ugyanezt, a hallgatóknak pedig az 55,3\%-a (Watkins-Lee 2010: 9.). A kutatás szerint a diákok számára a Facebook mint fontos kommunikációs csatorna is megjelenik, de mindkét vizsgált csoport (bár csak a válaszadók 32,8\%-a [Watkins-Lee 2010: 17.]) használja a kedvelt közösségi oldalt informális események szervezésére. A kutatás válaszadói alapvetố demográfiai szempontból a következők: a nôk 61,1\%-ot tettek ki, a fiatalok (18-25 év) pedig 54,5\%-ot (Watkins-Lee 2010: 4.). A kutatási beszámolóban több helyen is megjelenik az az állítás, hogy a férfiak jellemzóbben osztanak meg klipeket, videókat, míg a nók fotókat (Watkins-Lee 2010: 18-21.). Az egyetemistáknak 13,1\%-a jelölte, hogy a közösségi oldal a házi feladatában segítségére lenne (Watkins-Lee 2010: 23.). Nagyon jól mutatja az amerikai egyetemisták Facebookhoz való viszonyulását az is, hogy az egyik 20 éves egyetemista válaszadó azt kérdezte: Mit csinálnak az emberek Facebook nélkül?

Tulajdonképpen úgy túnik, hogy a mai felnövő generáció számára az élet elképzelhetetlen lett közösségi média nélkül (Watkins-Lee 2010: 2.). Érdekes módon viszont az egyetemisták 22,8\%-a egyetértett, vagy teljes mértékben egyetértett azzal az óhajjal, hogy „Bárcsak képes lennék kevesebb időt tölteni a Facebookon, mint amennyit jelenleg töltök!” (Watkins-Lee 2010: 9.) 
A magyar kutatást Györfi Anna (2011) kutatásvezető beszámolója alapján a KutatóCentrum 2011. január 13-18 között végezte a közösségi oldalak használatával kapcsolatosan a Marketing\&Média magazin megbízásából. A kutatás online formában zajlott le, 1714 főnyi minta jött létre. Ez a kutatás elsősorban a magyarok által használt közösségi oldalak népszerúségét volt hivatott összehasonlítani, amelyből megtudhatjuk, hogy ,a 18-24 éves kor közötti honfitársaink az amerikai közösségi hálózaton, a Facebook-on aktívabbak" (A fiataloknak a Facebook, az idősebbeknek az Iwiw kell 2011). A kutatási eredményekből én csak a Facebookhasználatot jellemző érdekesebb adatokat szeretném kiragadni. A válaszadók között a Facebook-on regisztráltak aránya 2010-ben 31\% volt, ez 2011-re 86\%-ra emelkedett, és ez utóbbi csoport 89\%-a aktív felhasználó (Györfi 2011), amely az összes ma Magyarországon használt közösségi oldal közül a legmagasabb arány. A „legtöbb lehetôséget a fiatalok aknázzák ki: a megkérdezett 18-24 évesek 45 százaléka gyakrabban használja a hasonló portálokat üzenetküldésre, mint e-mail fiókját, és közel felük szívesen telepít kisalkalmazásokat, illetve lép be különböző csoportokba" (A fiataloknak a Facebook, az idősebbeknek az Iwiw kell 2011). A válaszadók 19\%-a munkaidejében is látogatja kedvelt virtuális csoportjának oldalát (Györfi 2011). Sütő (2011: 11.) beszámolója alapján a kutatásban a legfiatalabb csoport a 18-24 évesek csoportja volt, és ennek a csoportnak mindössze 7\%-a nem tagja a Facebooknak, további egy $1 \%$-a pedig olyan, aki tagja ugyan, de nem látogatja az oldalt. A maradék 92\% ebből következően rendszeres Facebook-használó. Ez a csoport markánsan eltér ezen a téren az idősebb korosztálytól, mivel az aktív tagság egyik további vizsgált korcsoportban sem éri el a 80\%-ot. Nem és településtípus szempontjából nincsenek jelentős eltérések az aktív Facebook-használat tekintetében, viszont a Facebookon aktív felhasználók 98\%-a más közösségi oldalon is regisztrált (Sütő 2011: 16.).

\section{Saját kutatás}

A PTE BTK Szociológia Tanszékén, az Adatelemzés II. kurzus keretében lefolytatott kutatásban a Facebook használati szokásait mértük fel a középiskolások és egyetemisták körében. A kutatás során a „Facebook-jelenség” számos aspektusát megvizsgáltuk, többek között a közösségi oldalon eltöltött idő mennyiségét, a tevékenységek körét és a használat hatásait a diákok mindennapjaira.

A mintavétel során az akkor legfrissebb, 2005-ös Mikrocenzus adatait vettük alapul (Mikrocenzus, 2005). A 14-23 éves korosztály tíz korévcsoportját, illetve annak nemi megoszlását figyelembe véve készítettük el a kvóta szerinti mintavétel irányszámait, amely által az országos adatok 0,03\%-os mintájának létrehozását irányoztuk elő.

A lekérdezés főként papír alapú, önkitöltős kérdőívvel történt, mellyel összesen 390 diákot, illetve hallgatót kerestünk meg. A középiskolás tanulók a kérdőíveket osztályfőnöki órákon töltötték ki, az egyetemi hallgatókat pedig az előadások, szemináriumok közti szünetekben keresték fel a kutatást készítő hallgatók. A papír alapú lekérdezést kiegészítve a csoportból Lázár Erika (2011) készített egy online kérdőívet 
is a Survey Monkey ${ }^{1}$ rendszer segítségével, mely 63 válaszadó adataival bóvítette az adatbázist. A papír alapú lekérdezést tizennégy hallgató végezte el két hét alatt (2011. október 16-ától 27-éig). Az adatbázisba végül 453-an kerültek be, köztük (akikről vannak erre irányuló adataink) 202 középiskolai diák (10 pécsi ${ }^{2}$ és 7 nem pécsi ${ }^{3}$ középiskola) és 238 egyetemi hallgató, legjellemzóbb módon a Pécsi Tudományegyetem karairól. A kérdőívből kinyerhető empirikus adatokat kódolás után a hallgatókkal számítógépes adatbázisba rögzítettük, azokat ellenőriztük és tisztítottuk.

Jelen munkám kezdetén azt feltételeztem, hogy az inkább számítógépen felnőtt tanulók, a „Z generáció”4 tagjai máshogy használják a Facebookot, mint idősebb, kevésbé digitális korban nevelődő egyetemista társaik. Az adatelemzést SPSS 20.0 programban és a Microsoft Excel Adatelemzés moduljának igénybevételével végeztem, leíró és többváltozós statisztikai eszközök alkalmazásával.

\section{Eredmények}

Elemzésem során a következő kérdésekre keresem a választ: Van-e eltérés a tanulók és a hallgatók között? Elkülönül-e egymástól a két csoport a Facebookhasználat tekintetében? Létrehozhatók-e csoportok a válaszadó diákokból?

Először a Facebook-használat gyakoriságát hasonlítottam össze a két csoportban, de - ahogy az a két hisztogramból látható - nincs érdemi különbség a két csoport között.

\section{2-3. ábra: A Facebook-használat gyakorisága az iskolatípus mentén bontva (fö)}
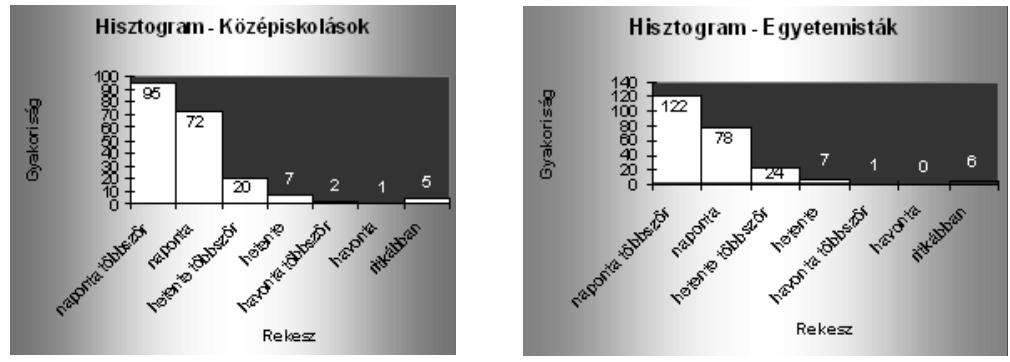

Forrás: saját szerkesztés

1 Online kérdőív- és adatbázis-készítő rendszer, http://www.surveymonkey.net (2011. 11. 19.)

2 Múvészeti Gimnázium és Szakközépiskola, Janus Pannonius Gimnázium, Kereskedelmi Szakközépiskola, Széchenyi István Gimnázium és Szakközépiskola, Apáczai Csere János Gimnázium, Zipernowsky Károly Múszaki Szakközépiskola, Leőwey Klára Gimnázium, A Ciszterci Rend Nagy Lajos Gimnáziuma, Babits Mihály Gyakorló Gimnázium és Szakközépiskola, Református Kollégium

3 Barcs, Budapest, Dombóvár, Kecskemét, Lenti, Szigetvár, Szolnok

4 „A mai 12-25 évesek, akiket gyakran Y - illetve a fiatalabb tinédzser korosztályt - Z generációnak is neveznek, a bébi-harcosok vagy egyszerúen: a következő generáció". (Tari é. n.) 
Ezután megvizsgáltam minden olyan változót, amely a Facebookkal kapcsolatos mennyiségi paraméternek tekinthető (a következő táblázatban láthatók a kerekített átlagok, valamint a szignifikanciaértékek).

1. táblázat: A Facebookos kutatás mennyiségi változóinak alapvetó jellemzói (mértékegység, egyetemisták és középiskolások átlaga, a két átlag közötti különbséghez rendelhetô szignifikanciaérték)

\begin{tabular}{|c|c|c|c|c|}
\hline Kérdések & Me. 5 & $\begin{array}{c}\text { Közép } \\
\text {-iskolások }\end{array}$ & $\begin{array}{l}\text { Egyete } \\
\text {-misták }\end{array}$ & Sig6 \\
\hline $\begin{array}{l}\text { Mennyi szabadidőd van egy hétköznap általában } \\
\text { (iskolán, alváson, evésen, tisztálkodáson kívül)? }\end{array}$ & Óra & 4,7 & 5,7 & $0,000 * *$ \\
\hline $\begin{array}{l}\text { Ennek kb. hány százalékát töltöd összesen a szabadban } \\
\text { vagy mozgással, vagy személyes kapcsolattal? }\end{array}$ & $\%$ & 51,56 & 44,46 & $0,005 * *$ \\
\hline $\begin{array}{l}\text { Alkalmanként általában mennyi időt töltesz } \\
\text { aktív Facebookozással? }\end{array}$ & Perc & 43 & 33 & $0,014^{*}$ \\
\hline $\begin{array}{l}\text { A Facebookon töltött időd hány százalékát } \\
\text { töltöd cseteléssel? }\end{array}$ & $\%$ & 41,86 & 29,90 & $0,000 * *$ \\
\hline $\begin{array}{l}\text { Hetente átlagosan mennyi időt töltesz } \\
\text { Facebookozással? }\end{array}$ & Óra & 11,7 & 11,8 & 0,917 \\
\hline $\begin{array}{l}\text { Nagyságrendileg hányszor lépsz fel a Facebookra... } \\
\text { - egy átlagos hétköznap? }\end{array}$ & $\mathrm{Db}$ & 4 & 4 & 0,894 \\
\hline $\begin{array}{l}\text { Nagyságrendileg hányszor lépsz fel a Facebookra... } \\
\text { - egy átlagos hétvégi nap? }\end{array}$ & $\mathrm{Db}$ & 6 & 5 & 0,579 \\
\hline
\end{tabular}

Forrás: saját szerkesztés

Ebből az látszik, hogy a középiskolások átlagosan többet vannak „,nem számítógép előtt", viszont egy-egy alkalommal több időt töltenek aktív facebookozással és a Facebookon töltött idejük lényegesen nagyobb arányát fordítják csetelésre, míg az egyetemistáknak átlagosan naponta eggyel több szabad órájuk van. A többi szempontból nincs érdemi különbség a két csoport között.

Ahhoz, hogy a válaszadókat K-közepú klaszteranalízis segítségével megpróbáljam csoportokba sorolni, előbb dimenzió-redukciót hajtottam végre két főkomponens-elemzéssel, hogy a késóbbi eredmények megfoghatóbbak, átláthatóbbak legyenek. Az első ${ }^{7}$ eredményeként részint a fentiekben bemutatott, a Facebookkal közvetlenül összefüggésbe hozható mennyiségi paraméterekből, részint ordinális változók átkódolása után nyert skálatípusú változókból egy főkomponens jött létre, melyet „Mennyiség”-nek neveztem el.

\section{Mértékegység}

6 A kétmintás t-próbákhoz rendelhető szignifikanciaérték a szórásegyezőség (Levene-teszt) figyelembevétele mellett, ahol az 5\%-os $(*)$ / a minden ésszerú $(* *)$ szignifikanciaszint mellett érdemi különbség van a két csoport átlaga között.

$7 \quad \mathrm{KMO}=0,621$, Bartlett $=0,000$ - tehát főkomponens-elemzésre alkalmasak az adatok, a kommunalitások megfelelőek; a teljes megmagyarázott varianciahányad=41,65\%, azaz a keletkező főkomponens az eredeti hatdimenziós változótér információtartalmának 41,65\%-át fedi le. 
A második fơkomponens-elemzés ${ }^{8}$ során 28 ordinális vagy nominális változót használtam fel, ezek olyan jellegú információkat tömörítettek, mint hogy a Facebookon mit tesz közzé magáról a válaszadó, milyen alkalmazásokat használ, hogy áll hozzá az ismeretlenekhez, és tanulással kapcsolatos tevékenységeket végez-e. A létrejött öt főkomponens a következő jellemzókkel bír:

Az első a „Közösségi élet” nevet kapta, mivel ebben vannak az olyan típusú változók, mint a megosztások közzététele, házikkal kapcsolatos kommunikáció, a kommentelés, csetelés, like-olás gyakorisága. A második az „Alapvető információk” nevet kapta, mivel ez olyan változók információtartalmát tömöríti, amelyeket a legtöbb Facebookot használó magáról közzétesz, mint a kép, rokonok, születési év, iskola, munkahely. A harmadik főkomponenst a „Speciális információk” név fémjelzi, mivel e kategória alá tartozó adatok közzététele már kevésbé jellemző, mint pl. a politikai és a vallási hovatartozás, a lakcím és a telefonszám. Az „Alkalmazások” nevet adtam a negyedik fookomponensnek, mivel ebben a puszta kapcsolattartáson túlmutató szórakoztató alkalmazások használatának gyakoriságát mérő változók kaptak helyet, mint a játék, videó, egyéb szórakoztató lehetőségek. És végül az ötödik főkomponens tömöríti a „Káros hatások”-at, ez alá sorolódott be ugyanis a „Facebook-használat a tanulás / a személyes kapcsolat / az alvás rovására megy" állítást mérő változók csoportja.

2. táblázat: A Facebookos kutatás klaszteranalízisének eredménye

\begin{tabular}{|c|c|c|c|c|c|}
\hline \multirow[t]{2}{*}{ Bevont változók } & \multicolumn{5}{|c|}{ Klaszterek $(n=175)^{9}$} \\
\hline & „óvatos duhaj" & $\begin{array}{c}\text { Z generáció- } \\
\text { fiúk }\end{array}$ & $\begin{array}{c}\text { Z generáció - } \\
\text { kapcsolattartó } \\
\text { lányok }\end{array}$ & $\begin{array}{c}\text { Z generáció - } \\
\text { atomizált } \\
\text { lányok }\end{array}$ & $\begin{array}{c}\text { „a részvétel } \\
\text { a fontos" }\end{array}$ \\
\hline Mennyiség & $\begin{array}{c}\text { átlagnál } \\
\text { kevesebb }\end{array}$ & legkevesebb & $\begin{array}{c}\text { átlagnál } \\
\text { kevesebb }\end{array}$ & legtöbb & átlagos \\
\hline Közösség & $\begin{array}{c}\text { átlagnál } \\
\text { kevesebb }\end{array}$ & legtöbb & átlagnál több & legkevesebb & átlagos \\
\hline Alapinfók & átlagnál több & legkevesebb & átlagnál több & $\begin{array}{c}\text { átlagnál } \\
\text { kevesebb }\end{array}$ & legtöbb \\
\hline Spec_infók & legkevesebb & átlagos & $\begin{array}{c}\text { átlagnál } \\
\text { kevesebb }\end{array}$ & átlagos & legtöbb \\
\hline Alkalmazások & átlagos & sok & legkevesebb & sok & átlagos \\
\hline Káros_hatás & legtöbb & $\begin{array}{c}\text { átlagnál } \\
\text { kevesebb }\end{array}$ & kevés & legkevesebb & $\begin{array}{c}\text { átlagnál } \\
\text { kevesebb }\end{array}$ \\
\hline Kor_st & egyetemisták & $\begin{array}{c}\text { középiskolás } \\
\text { inkább }\end{array}$ & $\begin{array}{c}\text { középiskolás } \\
\text { inkább }\end{array}$ & középiskolások & vegyes \\
\hline Nem_st & inkább lányok & sok fiú & sok lány & inkább lányok & sok fiú \\
\hline Arány & $30 \%$ & $25 \%$ & $23 \%$ & $13 \%$ & $9 \%$ \\
\hline
\end{tabular}

Forrás: saját szerkesztés

$8 \quad \mathrm{KMO}=0,781$, Bartlett = 0,000 - tehát főkomponens-elemzésre alkalmasak az adatok, a kommunalitások megfelelőek; a teljes megmagyarázott varianciahányad=48,85\%, azaz a keletkező fôkomponensek az eredeti huszonnyolc-dimenziós változótér információtartalmának 48,85\%-át fedik le.

9 A főkomponens-elemzések miatt a válaszadók több mint fele kiesett a klaszterelemzésből, hiszen elég volt az érintett körülbelül negyven kérdésből egy, amelyre az adott válaszadó nem válaszolt, és máris kiesett minden további elemzésből. 
A hat fookomponensre, valamint a kor és a nem standardizált értékére futtattam egy k-közepú klaszteranalízist (öt középponttal). Az ANOVA tábla szignifikanciaértékei alapján $\left(\mathrm{p}_{\max }=0,004\right)$ minden bevont változó szerint lényeges eltérés van a keletkező öt csoport átlagai között. Az eredmény a következő táblázatban látható (a csoportok sorrendjét a méretük szerint csökkenően határoztam meg).

A legjelentősebb, vagyis legtöbb válaszadót (30\%) tömörítő csoport az „óvatos duhaj” nevet kapta, mivel ők azok az elsősorban egyetemista lányok, akik az alapinformációkat szívesen teszik közzé magukról, továbbá leginkább az jellemző rájuk, hogy a Facebook potenciális káros hatásait a legveszélyesebbnek érzékelik a többi csoporthoz viszonyítva.

A második legtöbb válaszadó (25\%) a „Z generációs fiúk”-at tömöríti. Ők ülnek a legkevesebbet a Facebook előtt, akkor viszont két dolgot csinálnak, részint komoly közösségi életet élnek, vagy használják a szórakozási célú alkalmazásokat. Ezen csoport tagjai nem szívesen tesznek közzé magukról alapinformációkat (azaz az internet személytelenségébe burkolóznak).

A harmadik (23\%) a ,Z generációs kapcsolattartó lányok” csoportja. Rájuk is jellemző a közösségi tevékenységek folytatása a Facebookon (nem olyan mértékben, mint a Z generációs fiúk csoportjára), szívesen tesznek közzé magukról alapinformációkat, nem használnak szórakoztató alkalmazásokat, és a többi csoport tagjainál kevésbé érzékelik a virtuális tér káros hatásait.

Negyedik csoportba (13\%) tartoznak a veszélyeztetett ,Z generációs atomizált lányok”. OOk ,lógnak” a legtöbbet időben a Facebookon, viszont nem közösségi tevékenységeket ûznek, hanem elsôsorban a szórakozási célú alkalmazások használatával élnek, és ók érzékelik / feltételezik legkevésbé, hogy a Facebook káros lehet akár a tanulásra, akár az egészségükre vagy a személyes kapcsolatrendszerükre.

Az ötödik csoport (9\%) életkor tekintetében vegyes (tehát nem mondható, hogy itt jellemzően középiskolások vagy egyetemisták találhatók), de főleg fiúkat tömörít. Azért adtam neki a ,részvétel a fontos” nevet, mert a csoport tagjai jelen vannak a Facebookon, ők teszik közzé magukról a legtöbb információt, kevéssé érzékelik a káros hatásokat; hiszen talán ők azok, akik a Facebookot „rendeltetésszerúen" használják - ha egyáltalán ilyen létezik.

\section{Összegzés}

Munkám célja az volt, hogy a Facebook-használat bemutatása néhány korábbi kutatás eredményeinek tükrében, valamint a PTE BTK Szociológia Tanszékének hallgatói által végzett adatfelvétel adatbázisán végzett elemzés keretében összehasonlítsam a magyar középiskolások és egyetemisták Facebook-használatát.

Az elemzésből kiderült, hogy

1. szépen elkülönülő csoportok jöttek létre a lehatárolt főkomponensek mentén,

2. a kor is differenciált az egyes csoportokban - azaz a középiskolások és az egyetemisták szétválaszthatók többnyire, tehát 
a hipotézisem, miszerint a középiskolások és az egyetemisták máshogy használják a Facebookot, az elemzésem fényében alátámasztott. Egy csoport van mindössze, ahol nem különül el a két korosztály, ez pedig az ötödik, ide olyan fiatalok tartoznak, akik jelen vannak, de nem igazán használják ki a Facebook adta, potenciálisan függőséget generáló lehetőségeket. Az eredményekből nagyon szépen látszik, hogy a fiatalabb (Z generációs) korosztály kevéssé érzékeli a káros hatásokat, míg az idősebbek, közülük is főleg a lányok látják a Facebook lehetséges veszélyeit.

\section{Hivatkozott irodalom}

BALlis, MARY (é. n.): Who Invented Facebook? The history behind the number one social media network Facebook. Internet: http://inventors.about.com/od/ fstartinventions/a/Facebook.htm, letöltve: 2012. 03. 26.

Foster, Ben (2012): Facebook User Growth Chart. Internet: http://www.benphoster.com/facebook-user-growth-chart-2004-2010/, letöltve: 2012. 0420.

GYÖRFI ANNA (2011): Mindenki a Web2-n? Internet: http://www.kutatocentrum.hu/ tanulmanytar/2011/cikk-12/mindenki-a-web2-n, letöltve: 2012. 04. 18.

Joinson, AdAm N. (2008): 'Looking at', 'Looking up' or 'Keeping up with' People? Motives and Uses of Facebook. In Proceedings of the 2008 (26th) Conference on Human Factors in Computing Systems (CHI). Florence, Italy, April 5-10, 2008.

LÁZÁR ERIKA (2011): Facebook-kérdőív. Internet: http://www.surveymonkey.com /s/facebook_kerdoiv, letöltve: 2011.11. 19.

PRIEVARA TiBOR (é. n.): Facebook az életünkben - kutatás. Internet: http://tanarblog. hu/in-ternet-a-tanoran/1761-facebook-az-eletuenkben-kutatas, letöltve: 2011. 03. 31.

SüTő ANNA (2011): Mindenki a Web2-n? Internet: http://www.kutatocentrum.hu/ images/galery/tantar_12_hun.pdf, letöltve: 2012.03. 30.

TARI ANNAMÁRIA (é. n.): Az Y és mögötte a Z generáció. Internet: http://www. budapestedu.hu/data/cms47443/okopannon_tari.pdf, letöltve: 2012. 04. 20.

TóTh-MÓzer SzILviA-LÉvai DóRA (2011): Javithatja-e a Facebook a tanár-diák kapcsolatot? Internet: http://www.slideshare.net/tothmozer/facebookkutats, letöltve: 2012. 03. 25.

Valenzuela, Sebastian-Park, NAmsu-Kee, Kerk F. (2009): Is There Social Capital in a Social Network Site? Facebook Use and College Students'Life Satisfaction, Trust, and Participation. Journal of Computer-Mediated Communication 14 (4), 875-901.

Viswanath, Bimal-Mislove, Alan-Cha Meeyoung-Gummadi, Krishna P. (2009): On the Evolution of User Interaction in Facebook. In Proceedings of the 2nd ACM SIGCOMM Workshop on Social Networks (WOSN), Barcelona, Spain, August 2009.

Watkins, S. CRAIG-LeE, H. ERIN (2010): Got Facebook? Investigating What's Social About Social Media, Internet: http://www.theyoungandthedigital.com/wp- 
content/uploads/2010/11/watkins_lee_facebookstudy-nov-18.pdf, letöltve: 2012. 03. 30.

Zhao, Shanyang-Grasmuck, Sherri-Martin, Jason (2008): Identity Construction on Facebook: Digital Empowerment in Anchored Relationships. Computers in Human Behavior 24 (5), 1816-1836.

A fiataloknak a Facebook, az idősebbeknek az Iwiw kell (2011): Internet: http://einclusion.hu/2011-03-10/a-fiataloknak-a-facebook-az-idosebbeknek-az-iwiwkell/, letöltve: 2012. 03. 30.

Cisco Connected World Technology Report (2011): Internet: http://www.cisco. com/en/US/solutions/ns341/ns525/ns537/ns705/ns1120/2011-CCWTRChapter-3-All-Finding.pdf, letöltve: 2012. 04. 10.

Mikrocenzus 2005. (2005): 2. A népesség és a lakások jellemzői /2. Részletes adatok / 2.1. Demográfia / 2.1.1 A népesség korév és nemek szerint, a nemek aránya. Internet: http://www.mikrocenzus.hu/mc2005_hun/kotetek/02/ tables/load2_1_1.html, letöltve: 2011. 10. 04. 